The Effect of Adding Crystalline Silicotitanate on the Durability, Liquidus, and Viscosity of Simulated High-Level Waste Glasses at Savannah River Site

by

J. R. Harbour

Westinghouse Savannah River Company

Savannah River Site

Aiken, South Carolina 29808

T. B. Edwards

R. J. Workman

A document prepared for SCIENTIFIC BASIS FOR NUCLEAR WASTE MANAGEMENT, XXIII AT MATERIALS RESEARCH SOCIETY MEETING at Boston, MA, USA from 11/29/99 - 12/2/99.

DOE Contract No. DE-AC09-96SR18500

This paper was prepared in connection with work done under the above contract number with the $U$. $S$.

Department of Energy. By acceptance of this paper, the publisher and/or recipient acknowledges the U. S. Government's right to retain a nonexclusive, royalty-free license in and to any copyright covering this paper, along with the right to reproduce and to authorize others to reproduce all or part of the copyrighted paper. 


\section{DISCLAIMER}

This report was prepared as an account of work sponsored by an agency of the United States Government. Neither the United States Government nor any agency thereof, nor any of their employees, makes any warranty, express or implied, or assumes any legal liability or responsibility for the accuracy, completeness, or usefulness of any information, apparatus, product or process disclosed, or represents that its use would not infringe privately owned rights. Reference herein to any specific commercial product, process or service by trade name, trademark, manufacturer, or otherwise does not necessarily constitute or imply its endorsement, recommendation, or favoring by the United States Government or any agency thereof. The views and opinions of authors expressed herein do not necessarily state or reflect those of the United States Government or any agency thereof.

This report has been reproduced directly from the best available copy.

Available for sale to the public, in paper, from: U.S. Department of Commerce, National Technical Information Service, 5285 Port Royal Road, Springfield, VA 22161,

phone: (800) 553-6847,

fax: (703) 605-6900

email: orders@ntis.fedworld.gov

online ordering: http://www.ntis.gov/ordering.htm

Available electronically at http://www.doe.gov/bridge

Available for a processing fee to U.S. Department of Energy and its contractors, in paper, from:

U.S. Department of Energy, Office of Scientific and Technical Information, P.O. Box 62,

Oak Ridge, TN 37831-0062,

phone: (865)576-8401,

fax: $(865) 576-5728$

email: reports@adonis.osti.gov 
WSRC-MS-99-00687

Revision 0

\section{Keywords: DWPF, Salt Disposition, Cesium, Ion Exchange \\ THE EFFECT OF ADDING CRYSTALLINE SILICOTITANATE ON THE DURABILITY, LIQUIDUS, AND VISCOSITY OF SIMULATED HIGH-LEVEL WASTE GLASSES AT SAVANNAH RIVER SITE (U)}

By: J. R. Harbour, T. B. Edwards, and R. J. Workman

Savannah River Technology Center

Westinghouse Savannah River Company

Savannah River Site

Aiken, SC 29808

A paper proposed for presentation and publication in the Proceedings of the Scientific Basis for Nuclear Waste Management Symposium XXIII, November 29 to December 3, 1999, Boston, MA.

This paper was prepared in connection with work done under Contract No. DE-AC0989SR18035 with the U. S. Department of Energy. By acceptance of this paper, the publisher and/or recipient acknowledges the U. S. Government's right to retain a nonexclusive, royalty-free license in and to any copyright covering this paper, along with the right to reproduce and to authorize others to reproduce all or part of the copyrighted paper. 


$$
\text { WSR C-MS- } 99-00687
$$

\title{
THE EFFECT OF ADDING CRYSTALLINE SILICOTITANATE ON THE DURABILITY, LIQUIDUS, AND VISCOSITY OF SIMULATED HIGH-LEVEL WASTE GLASSES AT SAVANNAH RIVER SITE
}

\author{
J. R. HARBOUR, T. B. EDWARDS, R. J. WORKMAN \\ Westinghouse Savannah River Company, Aiken, SC 29808, john harbour@srs.gov
}

\begin{abstract}
This report provides a summary of the results obtained for a limited variability study for glasses containing Crystalline Silicotitanate (CST), Monosodium Titanate (MST), and either simulated Purex or HM sludge. Twenty-two glasses containing Purex sludge and three glasses containing HM sludge were fabricated and tested. The fabricated glasses were tested for durability using the 7-day Product Consistency Test (PCT) and characterized by measuring the viscosity at $1150^{\circ} \mathrm{C}$ and by determining an approximate, bounding liquidus temperature. The current models used by Defense Waste Processing Facility (DWPF) for predicting durability, viscosity, and liquidus temperature were applied to all 25 glasses. The goal of this work was to identify any major problems from a glass perspective, within the scope of this effort, which could potentially preclude the use of CST at DWPF.
\end{abstract}

\section{INTRODUCTION}

One of the alternative salt disposition flowsheets being considered by Savannah River Site (SRS) would require that the Defense Waste Processing Facility (DWPF) vitrify a coupled feed containing High Level Waste (HLW) and Crystalline Silicotitanate (CST). A glass variability study was therefore conducted to explore the processibility and product quality of the glass composition region for this alternative to the In-Tank Precipitation (ITP) Process. The objective of this study was to obtain information on the feasibility of incorporating anticipated levels of CST into DWPF glass with and without doubling the nominal levels of Monosodium Titanate (MST).

The glasses for this study were selected from a set of candidate glasses that involved Purex and HM sludge types, covered sludge loadings (in the glass) of 22,26 , and 30 oxide weight percent (wt \%), utilized CST loadings (in the glass) of 3, 6, and 9 oxide wt $\%$, and included MST concentrations (in the glass) at 1.25 and $2.5 \mathrm{wt} \%$. For each composition, the remainder of the glass consisted of a proprietary glass former composition developed by M. K. Andrews of Savannah River Technology Center (SRTC).

The selection of Purex sludge for this study was based on the knowledge that this sludge type has historically been the most difficult sludge to incorporate into glass. Depleted uranium was introduced into the simulated Purex sludge to represent the uranium content ( $~ 9 \mathrm{wt} \%$ oxide) of actual sludge.

One of the major elements of concern for this study was titanium, which the DWPF currently restricts to a value of less than $1 \mathrm{wt} \% \mathrm{TiO}_{2}$ in glass. The introduction of CST and MST in this study results in $\mathrm{TiO}_{2}$ levels in the glasses that significantly exceed the current limit. Furthermore, CST introduces proprietary components with unknown impact on glass quality and processing properties. 


\section{WSRC- mS - 99-00687}

The primary property of interest in this study was the durability (as measured by the 7-day Product Consistency Test, PCT [1]) of the test glasses. The PCT is the recognized standard for determining the durability of vitrified HLW, and the Environmental Assessment (EA) glass is the reference standard for assessing acceptable durability determined using the PCT. For a glass to demonstrate acceptable durability its PCT leach rate must be 2-sigma better than the PCT leach rate of the EA glass.

Processing properties of interest for these glasses included viscosity at $1150^{\circ} \mathrm{C}$ and liquidus temperature. Viscosity was measured at SRTC using a Harron viscometer. To gain insight into the liquidus property for the CST glasses, an effort was made to obtain an upper bound on the $\mathrm{T}_{\mathrm{L}}$ 's using isothermal holds at $900,950,1000$, and $1050^{\circ} \mathrm{C}$ and non-quantitative XRD evaluations with a sensitivity of $\sim 0.7$ to $1 \mathrm{wt} \%$ for crystalline Trevorite in the glass.

\section{RESULTS}

Measurements of the compositions of the test glasses were conducted by SRTC. Standards were included with the test glasses and bias-corrections were conducted for many of these measurements. The sum of oxides for all of these glasses fell within the interval of 95 to 105 $\mathrm{wt} \%$, a measure of the quality of the analytical results.

\section{Glass Durability: Product Consistency Test}

All of the CST glasses, after being batched and fabricated, were subjected to the 7-day PCT as an assessment of their durabilities [1]. More specifically, Method A of PCT (ASTM C1285) was used for these measurements. Durability is the critical product quality metric for vitrified nuclear waste. The PCT responses (for four elements: boron, silicon, sodium, and lithium) were normalized to the elemental concentrations in glass, and reported with units of grams-per-liter $(\mathrm{g} / \mathrm{L})$ using the measured, measured bias-corrected, and target compositions. In addition to the CST test glasses, the EA glass and an Approved Reference Material (ARM) standard glass were subjected to the PCT for validation to determine glass acceptability.

All 25 glasses were very durable as measured by the PCT. The PCT values clustered within the interval from 0.64 to $0.91 \mathrm{~g} / \mathrm{L}$ for boron for all of the Purex glasses except one and ranged from 0.37 to $0.43 \mathrm{~g} / \mathrm{L}$ for boron for the HM glasses. For comparison, the EA glass has a boron rate of $16.7 \mathrm{~g} / \mathrm{L}[1]$.

Figure 1 is a plot of the DWPF model that relates the common logarithm of the normalized PCT (in this case for $B$ ) to a linear function of a free energy of hydration term $\left(\Delta G_{p}, k c a l / 100 g\right.$ glass) derived from the glass (measured and bias-corrected) compositions [2]. Prediction limits (at 95\% confidence) for individual PCT results are also plotted around this linear fit. The PCT results for EA (shown as a diamond), ARM (shown as a "z"), and the CST glasses (shown as open squares) are presented on this plot. Note that the CST results reveal acceptable PCT values although they are not well predicted by the current DWPF durability model. Almost all of the PCT values for the CST glasses are slightly higher than the upper prediction limit. The behaviors of $\mathrm{Si}, \mathrm{Na}$, and $\mathrm{Li}$ release are similar to that of $\mathrm{B}$ : acceptable but unpredictable durabilities. 


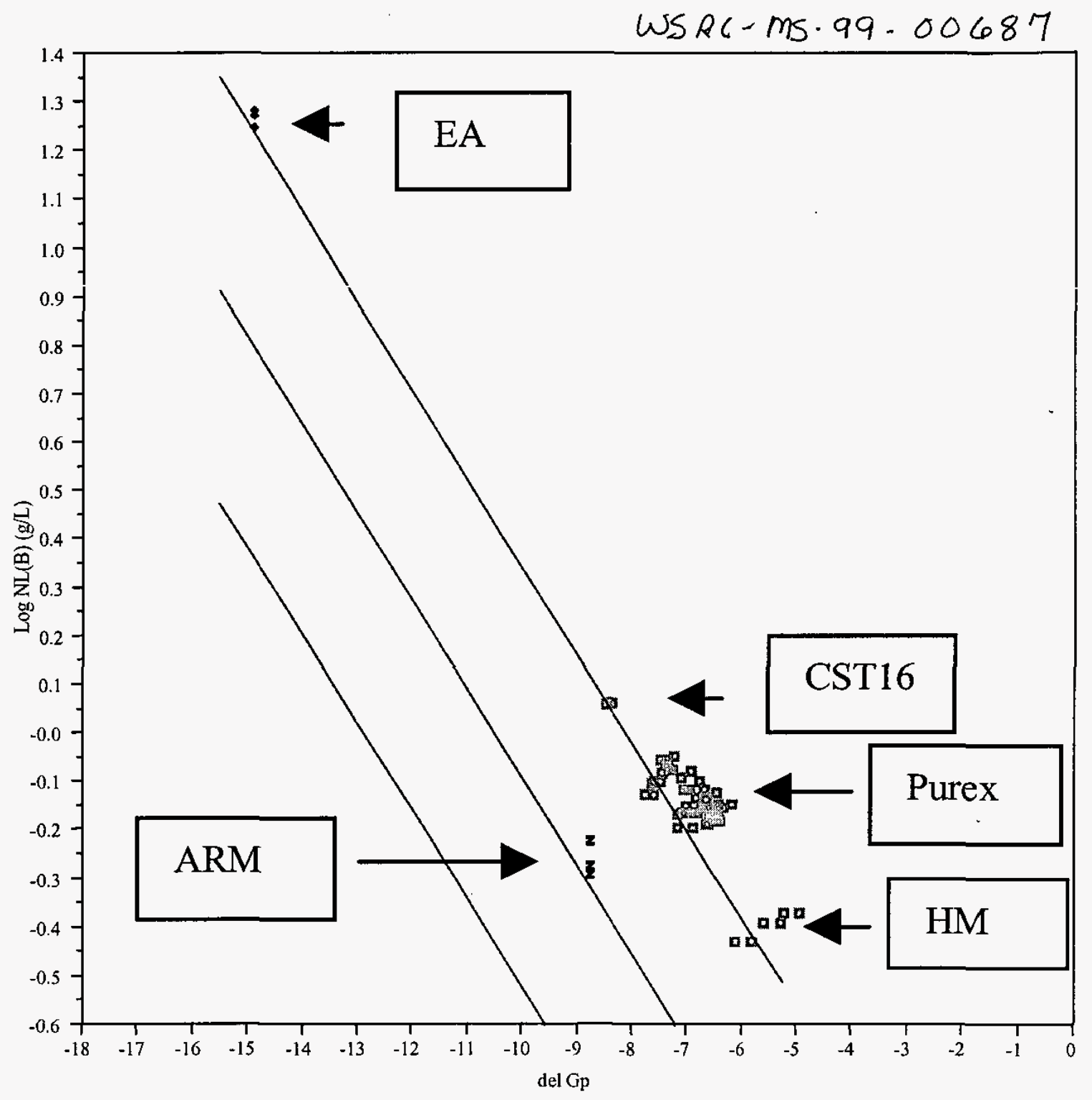

Figure 1

Log NL(B) (g/L) by del Gp(Using Measured \& Bias-corrected CST Glass Compositions \& EA and ARM reference compositions)

Figure 1 reveals that the PCT results for these CST glasses are consistently underpredicted by the current DWPF durability model. Possible reasons for this behavior include: (1) proprietary elements in CST not being adequately addressed by the current durability models, (2) the CST glasses may be phase separated thus violating one of the prerequisites for the use of the durability models and (3) a tendency for the durability models to underpredict glasses with $\Delta \mathrm{G}_{\mathrm{p}}$ values greater than $-8.5 \mathrm{kcal} / 100 \mathrm{~g}$ glass. 
Viscosity measurements were made on these CST glasses at SRTC using a Harrop, hightemperature viscometer. The viscosity, $\eta$, (in Poise) of each of these glasses at $1150^{\circ} \mathrm{C}$ was estimated $(\hat{\eta})$ from a Fulcher equation fitted to a set of viscosity measurements taken over an appropriate range of temperatures. The functional form of the (three-parameter) Fulcher equation (expressed in Poise) used to fit these data is given by equation (1):

$$
\ln \hat{\eta}=A+\frac{B}{(T-C)}
$$

where $\mathrm{A}, \mathrm{B}$, and $\mathrm{C}$ represent the parameters of the model that were determined from the available viscosity measurements at various temperatures (represented by $\mathrm{T}$, expressed in ${ }^{\circ} \mathrm{C}$ ). The fitted model was then used to predict the viscosity of the given glass at $1150^{\circ} \mathrm{C}$.

Figure 2 provides a plot of the measured viscosities versus the viscosities predicted from the DWPF model using target, measured, and bias-corrected compositions [3]. A 45-degree (diagonal) line is also shown for reference.

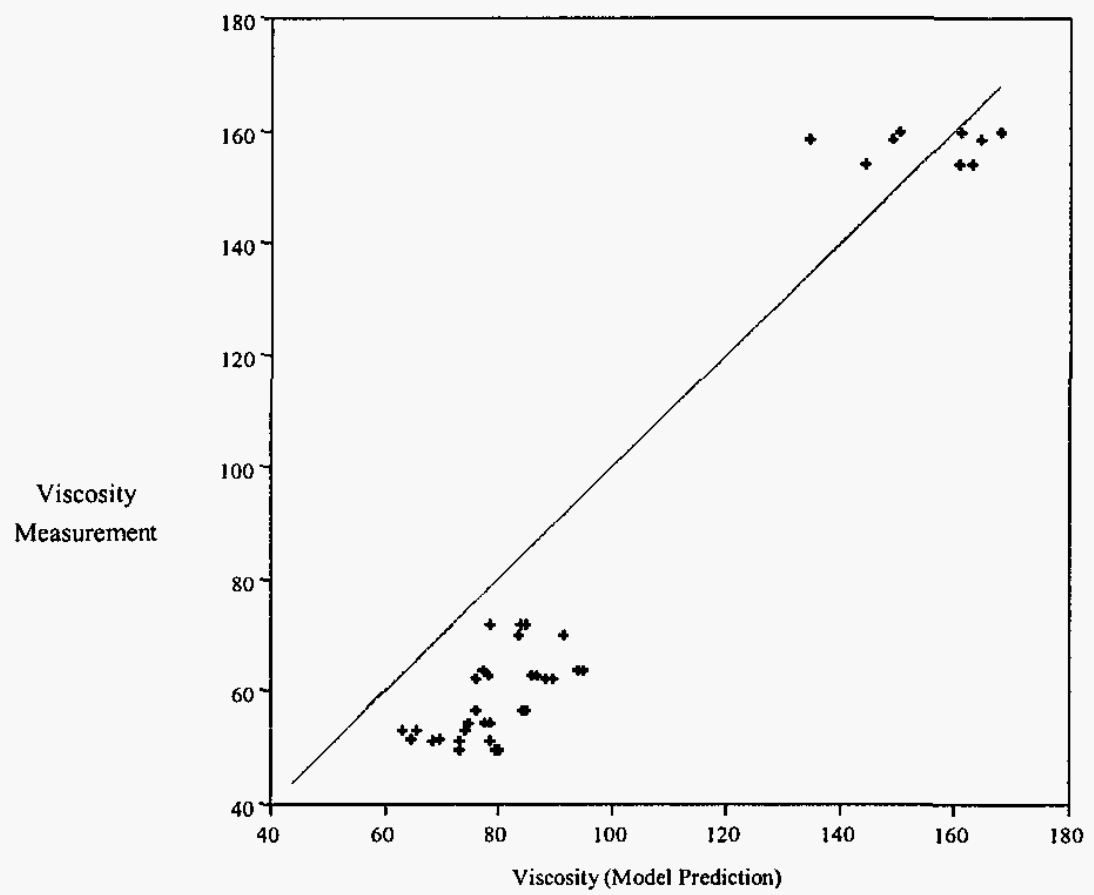

Figure 2: Viscosity Measurements versus Property Predictions in Poise

The melt viscosities at $1150^{\circ} \mathrm{C}$ for CST glasses fabricated using Purex are all well within the operating range for DWPF (20 to 100 Poise). Therefore, processing these glasses in the DWPF would not appear to be a problem from a viscosity perspective. The measured viscosities for all three of the HM glasses are well above the upper limit and, thus, outside of the operating window for DWPF. Although no Blend sludge (a sludge produced from blending of all the tank waste) glasses were fabricated, viscosity predictions for these glasses suggest that viscosity values may be close to 100 Poise, the upper limit for DWPF operations. 


$$
\text { WSRC.MS-99-00687 }
$$

There are several interesting trends observed in the data. Whether one uses the target, measured, or bias-corrected measured compositions to predict viscosities using the current model, the predicted viscosities are always higher than the measured viscosities for the glasses batched using Purex sludge. This may not be unexpected since some of the elements in CST and MST are not considered in the viscosity model. This overprediction does not occur for the glasses made using HM sludge. However, these viscosities are beyond DWPF's operating window. Further work may be required to include the additional elements introduced by CST into the viscosity model.

\section{Liquidus Temperature $\left(\mathbf{T}_{\underline{I}}\right)$}

Twenty-four hour isothermal holds at $50^{\circ} \mathrm{C}$ intervals were used to estimate the liquidus temperature. XRD was selected as the method of detection for crystal formation in the glasses after each isothermal hold. It is estimated that the sensitivity of XRD (non-quantitative) is $\sim 0.7$ to $1 \mathrm{wt} \%$ for a crystalline phase (in this case, Trevorite [4]). Therefore, for this type of measurement, absence of detection of a crystalline phase was evidence that the liquidus temperature is less than the temperature of that isothermal hold. On the other hand, detection of Trevorite (or any other primary crystalline phase) indicates that the liquidus temperature is higher than the temperature of the isothermal hold. The bounds on the liquidus temperatures for these CST glasses, estimated to the detection capabilities of XRD, are plotted against model predictions [3] in Figure 3. The points on the plot represent the lowest temperatures without crystal detection. A 45-degree (diagonal) line is also shown for reference.

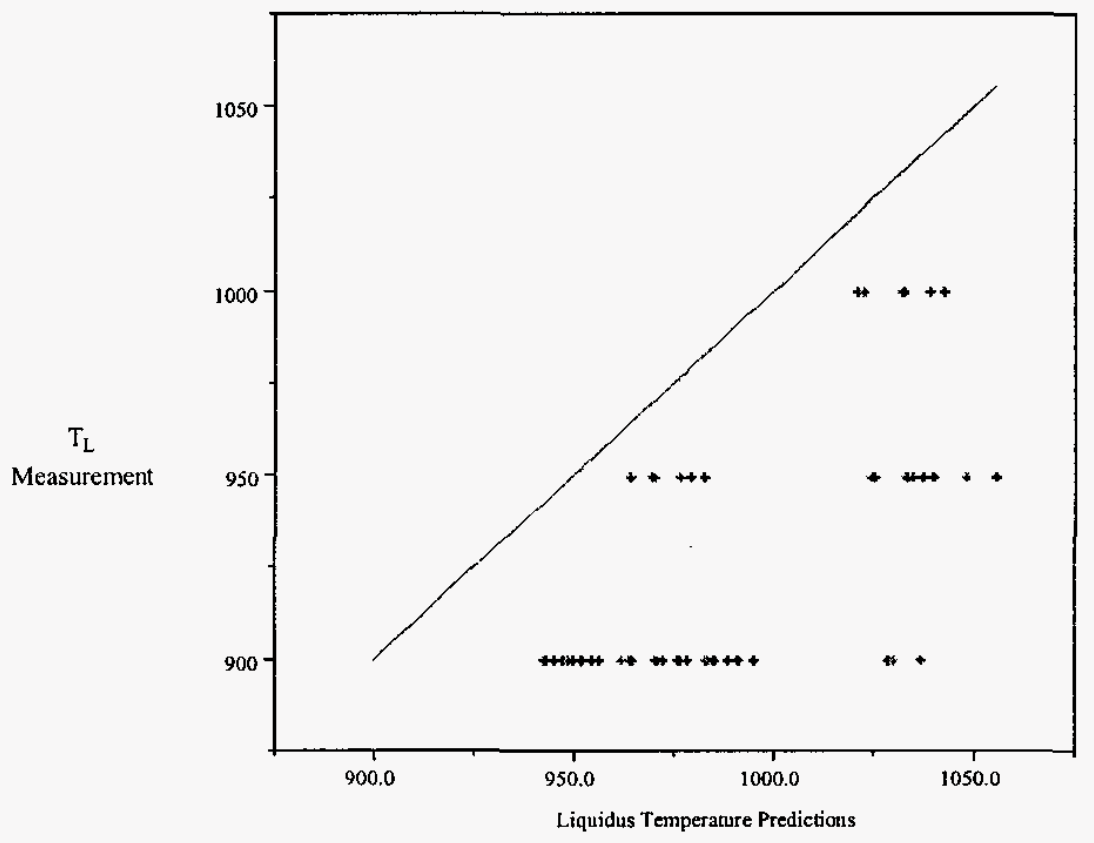

Figure 3: $\mathbf{T}_{\mathbf{L}}$ Measurements versus Property Predictions in ${ }^{\circ} \mathrm{C}$

The bounded estimates of $T_{L}$ suggest that the liquidus temperatures of these glasses are within the DWPF operating window for this property. The model predictions versus the bounding estimates suggest that the model may be conservative for these glasses. Therefore, it may be necessary to modify the liquidus temperature model to include elements of CST and prevent unnecessarily conservative constraints on this property.

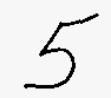




\section{CONCLUSIONS}

$$
\text { CWSRC-MS-99-00687 }
$$

All 25 glasses were very durable as measured by the PCT. The PCT values clustered within the interval from 0.64 to $0.91 \mathrm{~g} / \mathrm{L}$ for boron for all of the Purex glasses except one and ranged from 0.37 to $0.43 \mathrm{~g} / \mathrm{L}$ for boron for the HM glasses. For comparison, the reference EA glass had a boron PCT release of $16.7 \mathrm{~g} / \mathrm{L}$ [1]. A remarkable finding from this study was the highly clustered nature of the results. The 22 Purex-loaded glasses clustered tightly in one region, whereas the HM glasses clustered at an even lower value for boron release. These measured boron releases were generally greater than the upper $95 \%$ prediction limit of the model for these glasses. This type of behavior has been observed before for a range of glasses predicted to be very durable. The highly clustered nature of the results suggests that model revisions could be made to ensure predictability of the glasses.

For the $22 \mathrm{wt} \%$ Purex glasses, no crystals were detected in the bulk at $900^{\circ} \mathrm{C}$ or at the top surface of the glasses. For the $26 \mathrm{wt} \%$ Purex glasses, only two of the six glasses had bulk crystals after 24 hours at $900^{\circ} \mathrm{C}$, and crystallization was no longer evident after the 24 hour hold at $950^{\circ} \mathrm{C}$. For the $30 \mathrm{wt} \%$ Purex glasses, crystals were evident at higher temperatures but below the XRD detection limit at $1000^{\circ} \mathrm{C}$.

For the Purex containing glasses, all viscosities were well within the DWPF range of 20 to 100 poise. The viscosity model, in general, overpredicted the measured viscosities for these glasses. This is not surprising given the fact that the model was not developed for glasses incorporating CST elements. On the other hand, the HM sludge-containing glasses had, as predicted, viscosities at $1150^{\circ} \mathrm{C}(\sim 160$ Poise) that were far above the 100 Poise limit. Thus, the HM sludge-containing glasses fabricated would not be acceptable for processing in the DWPF.

These conclusions are limited by the scope of this task. One limitation of this scope was the absence of any investigation of kinetic effects. Thus, one can not rule out that amorphous phase separation occurs with centerline cooling, for example, and this could have a deleterious effect on the durability of the glass. A second limitation was the restriction on independent variation of chemical constituents. In a major variability study, ranges are established for each element, and a statistically designed set of glasses identified which not only covers a larger region of compositional space, but also provides the potential for revealing (or confirming) relationships between the properties and the glass compositions. A third limitation was that only approximate and bounding measurements of the liquidus temperatures were made.

\section{REFERENCES}

[1] ASTM C1285-97, "Standard Test Methods for Determining Chemical Durability of Nuclear Waste Glasses: The Product Consistency Test (PCT)," 1997.

[2] C. M. Jantzen, J. B. Pickett, K. G. Brown, T. B. Edwards, and D. C. Beam, "Process/Product Models for the Defense Waste Processing Facility (DWPF): Part I. Predicting

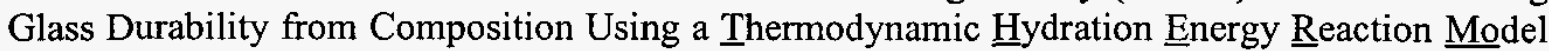
(THERMO) (U)," WSRC-TR-93-672, Rev. 1, September 28, 1995.

[3] K. G. Brown and R. L. Postles, "SME Acceptability Determination for DWPF Process Control (U),"WSRC-TR-95-0364, Revision 3, February 21, 1996.

[4] C. A. Cicero, S. L. Marra, and M. K. Andrews, "Phase Stability Determinations of DWPF Waste Glasses (U)," WSRC-TR-93-227, Revision 0, 1993.

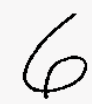

